\title{
Prevalence and Distribution of Common Barberry, the Alternate Host of Puccinia graminis, in Minnesota
}

P. D. Peterson, Clemson University, Pee Dee Research and Education Center, Florence, SC 29506; K. J. Leonard, Department of Plant Pathology, University of Minnesota, St. Paul 55108; J. D. Miller, USDA-ARS Northern Crop Science Laboratory, Fargo, ND 58105 (retired); R. J. Laudon, Minnesota Department of Agriculture, St. Paul 55107 (retired); and T. B. Sutton, Department of Plant Pathology, North Carolina State University, Raleigh 27695

\begin{abstract}
Peterson, P. D., Leonard, K. J., Miller, J. D., Laudon, R. J., and Sutton, T. B. 2005. Prevalence and distribution of common barberry, the alternate host of Puccinia graminis, in Minnesota. Plant Dis. 89:159-163.

A federal and state program operated from 1918 until the 1980s to eradicate common barberry (Berberis vulgaris), the alternate host of Puccinia graminis, from the major areas of cereal production in the United States. Over 500 million bushes were destroyed nationally during the program, approximately 1 million in Minnesota. Some sites in Minnesota where barberry bushes were destroyed remained in the "active" class when eradication was phased out in the 1980s. Active sites were defined as those on which there was still a possibility of emergence of barberry seedlings or sprouts arising from the parent bush. In the present study, from 1998 to 2002, 72 of the approximately 1,200 active sites in Minnesota were surveyed. Areas within $90 \mathrm{~m}$ of mapped locations of previously destroyed bushes were searched carefully at each site. Reemerged barberry plants were found on 32 sites. The reproductive status and GPS coordinates were recorded for each reemerged bush. More than $90 \%$ of the barberry bushes were found in counties with less than 400 ha of wheat per county, mostly in southeastern Minnesota, but one bush was found in a major wheat-producing county in northwestern Minnesota. Reemergence of barberry may serve as a source of new wheat stem rust races in future epidemics.
\end{abstract}

The common barberry (Berberis vulgaris L.), once planted as a popular ornamental shrub throughout the north central United States, has been responsible for initiating local, devastating epidemics of stem rust of small grains $(3,13)$. As the alternate host of Puccinia graminis Pers., the barberry serves as a local source of initial inoculum for stem rust as well as the site of sexual reproduction for the fungus, thus contributing to the development of new pathogen genotypes capable of attacking grain cultivars bred for rust resistance. In the early decades of the 1900 s, stem rust epidemics were common, particularly in the spring wheat growing region of the United States (7). When epidemics occurred, yield losses were frequently severe, reaching 50 to $70 \%$ over large areas, while individual fields were often totally destroyed.

Realizing the gravity of the situation in the aftermath of the staggering losses of

Corresponding author: P. D. Peterson

E-mail: ppeters@clemson.edu

This research was supported in part by the USDAARS Cereal Disease Laboratory, St. Paul, MN 55108 .

Accepted for publication 7 September 2004.

DOI: 10.1094/PD-89-0159

(C) 2005 The American Phytopathological Society wheat caused by the stem rust epidemics of 1916, 13 midwestern states and the USDA joined in a program 3 years later to eradicate rust-susceptible, common barberries (3). The major goal of the program was to break the rust life cycle and to prevent local outbreaks of stem rust in the important wheat growing states. The barberry eradication program continued and grew to 18 states before it was gradually phased out by 1980 . Over 500 million barberry bushes were destroyed in the eradication effort, and stem rust became a minor problem on wheat and other small grains toward the end of the program $(7,13)$.

When the USDA withdrew from the cooperative program in 1980, the responsibility for barberry eradication transferred to state regulatory agencies. After 1980, different states furnished monetary support for limited barberry eradication work. In Minnesota, small-scale barberry eradication efforts continued at the state level until 1990 to ensure that properties with active sites were periodically rechecked (10). Sites were considered "active" until all barberries were removed and the sites had been periodically rechecked for the absence of bushes over a span of at least 15 years. At the termination of the program in Minnesota, approximately 1,200 active sites remained to be rechecked (R. J. Laudon, unpublished). If bushes have reemerged on these active sites, they could serve as a source of inoculum for stem rust, provide a means for $P$. graminis to reproduce sexually and potentially produce new rust genotypes not found in the asexual rust population (7), and act as a seed source for further barberry spread (6).

Barberry bushes may have emerged on active sites in Minnesota after the eradication program ended. Barberry seeds can maintain viability in the soil for at least 7 years because of their durability to chemical and physical stresses (10). In addition, $B$. vulgaris can reproduce asexually by sprouts arising from underground rhizomes. Under ideal conditions, these bushes may bear fruit as early as 4 years after emergence (10). Thus, increase and spread of barberry may have occurred in the sites both locally asexually and more widely by seed since 1990 . Therefore, the objectives of this study were to (i) conduct a field survey of a subsample of the total number of active barberry sites in Minnesota to determine the prevalence of barberry on these sites and (ii) determine the distribution of currently active barberry sites in relation to the major wheat producing areas of Minnesota.

\section{MATERIALS AND METHODS}

For this survey, sites were chosen from approximately 1,200 currently active barberry sites in Minnesota. Information on these 1,200 active sites was obtained from archival data and historical records used during the Barberry Eradication Program, primarily Property Location Forms (Lforms) (Fig. 1). These L-forms document past eradication activity on individual barberry sites and provide specific information on site location, dates of survey, numbers of bushes found and destroyed, and methods of barberry eradication.

After an evaluation of the L-forms, 72 sites were selected from the 1,200 currently active sites in Minnesota. Criteria for selecting these sites included the high potential for barberry reemergence, coverage of a broad geographical area of the state, and any active sites in areas of major small grains production. These selected sites were distributed in central, northwest, southeast, southwest, south central, east central, and west central districts (Fig. 2, Table 1). The L-forms and archival data indicate that historically the southeastern district had the largest populations of bar- 
berry and the highest risk for reemergence (10); consequently, the majority of sites selected for this survey were located in the southeast. The northwest and west central districts are important areas of wheat production ( $>10,000 \mathrm{ha})$; therefore all existing active sites in these districts were included.

For this survey, individual sites were located using county, township, section, and property owner/occupant address and name information provided by the Lforms. Current county maps with section number were used to supplement this information. Township, section, and property owner/occupant address and name information were verified by the current property owner/occupant or nearby property owner. In a few cases, site information was verified at the county records office.

Detailed hand-drawn maps from the Lforms provide approximate locations of all past survey and eradication activity on an individual site (Figs. 1 and 3). These maps were used to identify the approximate location(s) of the most recent and all past bushes found and eradicated on each site in this survey. These locations served as the focal points from which each site survey was conducted. Once these approximate locations were ascertained, an immediate site check and random reconnaissance of the area to a $90-\mathrm{m}$ radius were conducted by two people. Signs of rust (pycnial and/or aecial stages) also were recorded. GPS coordinates were recorded on each site, and the locations of any bushes were added to the L-form maps. Surveys were conducted in April and October of 1998, 1999, 2000, and 2001 and April 2002. During these months, barberry are most visible and distinguishable from other bushes and shrubs because they produce their distinctive small pinnate leaves earlier than surrounding bushes in the spring and hold their leaves well into the fall months when surrounding bushes have shed their leaves.

\section{RESULTS}

A total of 662 barberry bushes were found on 32 of the 72 sites surveyed (Tables 1 and 2). All sites where bushes were located were sparsely or densely wooded. Sites with barberry had numbers of bushes ranging from one to 300 (Table 2). In 40 of the 72 sites, no barberry bushes were found; 15 sites had just one bush each; 10 sites had from two to five bushes each; and three sites had from seven to 13 bushes each. One site in Fillmore County had 159 bushes, and two sites in Winona County had 120 and 300 bushes, respectively (Table 2).

The distribution of barberry bushes on active sites in Minnesota was mainly limited to counties with less than 400 ha of wheat planted (Table 2). Only three barberry bushes were found in counties with more than 1,000 ha of wheat. One bush was in Becker County $(28,141$ ha wheat) in the northwest district; one was in Todd County $(2,154$ ha) in the central district; and one bush was in Dakota County, the only county in the southeast district with significant wheat production (1,030 ha) (Table 2). The second bush in the central district was found in Morrison County, which had only 346 ha wheat. No bushes were found in the southwest and west central districts where moderate amounts of wheat are grown. The greatest numbers of barberry bushes were found in the southeast district in Winona and Fillmore counties, with 46 and 92 ha planted to wheat, respectively. Of the 440 bushes found in Winona County, $95 \%$ occurred on just two of the five sites. Of the 183 bushes found in Fillmore County, $87 \%$ occurred on a single site. Goodhue and Houston counties each had 10 bushes distributed over several

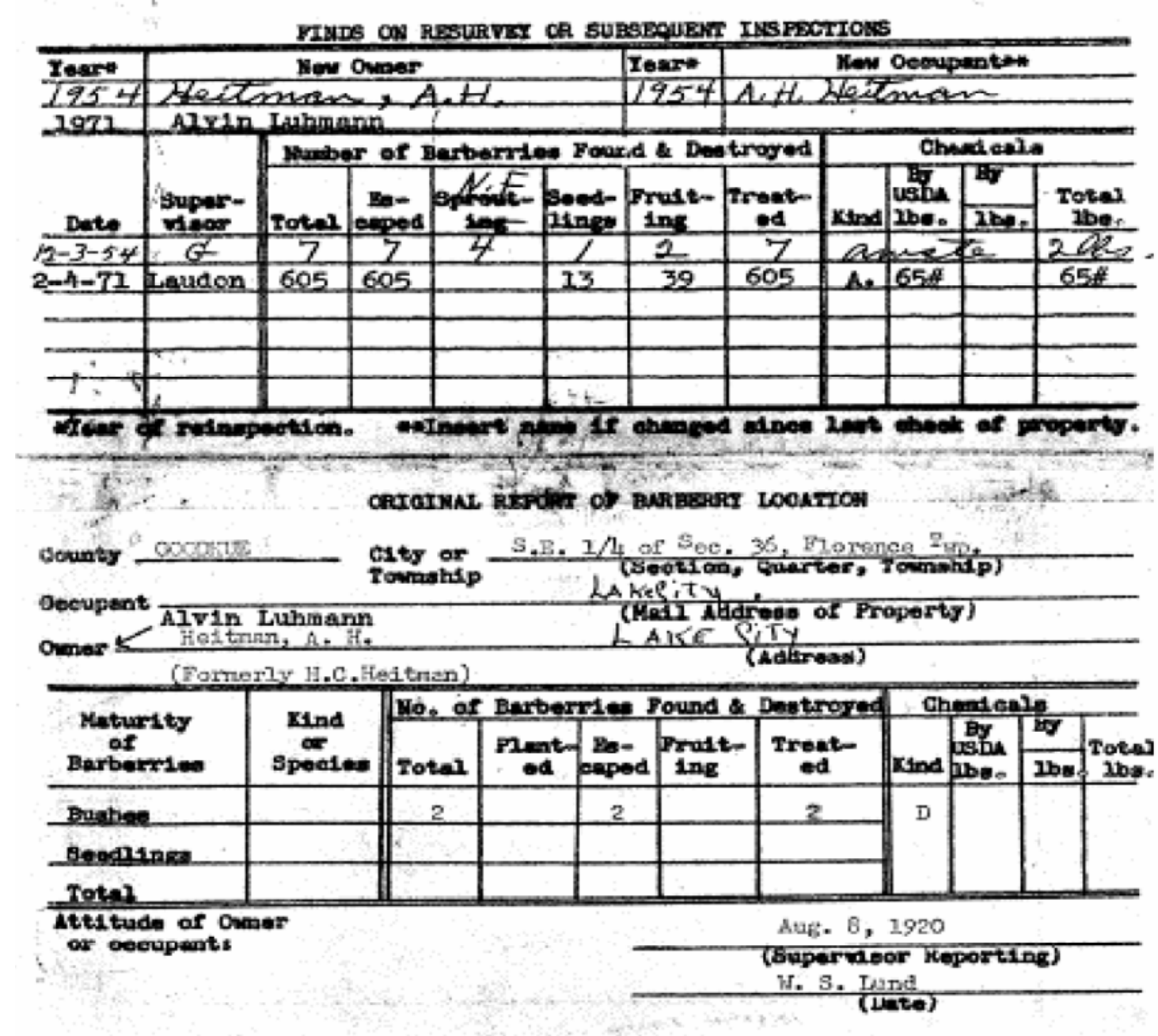

Fig. 1. Locator form (L-form) created in the 1920s and used to record data on barberry sites during the barberry eradication campaign. 
sites. The survey included only two sites in Olmstead County and a single site each in Dakota, Mower, and Wabasha counties. One of the sites in Olmstead County had four barberry bushes, and each site in Dakota, Mower, and Wabasha counties had only one (Table 2). In all, the southeast district accounted for $99 \%$ of the total 662 barberry bushes found in Minnesota from 1998 to 2003 (Table 1).

\section{DISCUSSION}

In the present survey, the focus was on active sites where barberry bushes had been identified and removed, and on the area within a 90-m radius of where each original bush was located. Most reproduction of barberry has been shown to result in localized dispersal $(10,12)$. On the other hand, barberry seeds can be distributed over greater distances by birds. Although the berries are not always their food of choice, many species of birds are attracted to the bright red berries of $B$. vulgaris when other food is scarce $(6,12)$. The seeds typically remain viable as they move through the birds' digestive tracts and sometimes are carried in flight to distances of several kilometers from the feeding site before being expelled. Some evidence exists to indicate that much longer disper- sal may occur occasionally when berries are consumed by migrating birds (6). Barberry seeds can remain dormant and viable in the soil for at least 7 years and often longer $(5,11,12)$. In addition, sprouts from underground rhizomes can enable the barberry to survive independently after the destruction of the parent bush. It is likely that most seeds deposited by birds great distances from the parent barberry bush will fall on sites unfavorable for germination and survival of a new barberry seedling. Nevertheless, sites with hundreds of barberry bushes such as those in Winona and Fillmore counties may have contributed to the spread of barberry bushes to new sites far enough away from the parent bushes to escape detection. These new sites would not exist in documented records of previous eradication activities and, thus, would be difficult to find.

Most of the sites where bushes have reemerged are in the southeast. There appear to be few sites with bushes in other areas of the state, particularly in the western districts. Aspects of barberry biology and ecology as well as previous eradication efforts probably influenced this distribution of bushes. The first barberry bushes introduced in Minnesota were planted in the southeast where alkaline, sandy loam soils (1) and abundant moisture favor their growth and reproduction over other areas of the state where soils are typically heav-

Table 1. Number of counties surveyed, sites visited, numbers of sites with bushes, and total numbers of barberry bushes found on selected active sites in Minnesota surveyed between 1998 and 2002

\begin{tabular}{lcccc}
\hline District & $\begin{array}{c}\text { Counties } \\
\text { surveyed }\end{array}$ & Sites visited & $\begin{array}{c}\text { Sites with } \\
\text { bushes }\end{array}$ & $\begin{array}{c}\text { Total number } \\
\text { of bushes }\end{array}$ \\
\hline Central & 3 & 14 & 2 & 3 \\
East central & 1 & 1 & 1 & 1 \\
Northwest & 2 & 4 & 1 & 1 \\
South central & 4 & 9 & 1 & 1 \\
Southeast & 8 & 31 & 27 & 656 \\
Southwest & 2 & 3 & 0 & 0 \\
West central & 2 & 10 & 0 & 0 \\
Total & 22 & 72 & 32 & 662 \\
\hline
\end{tabular}

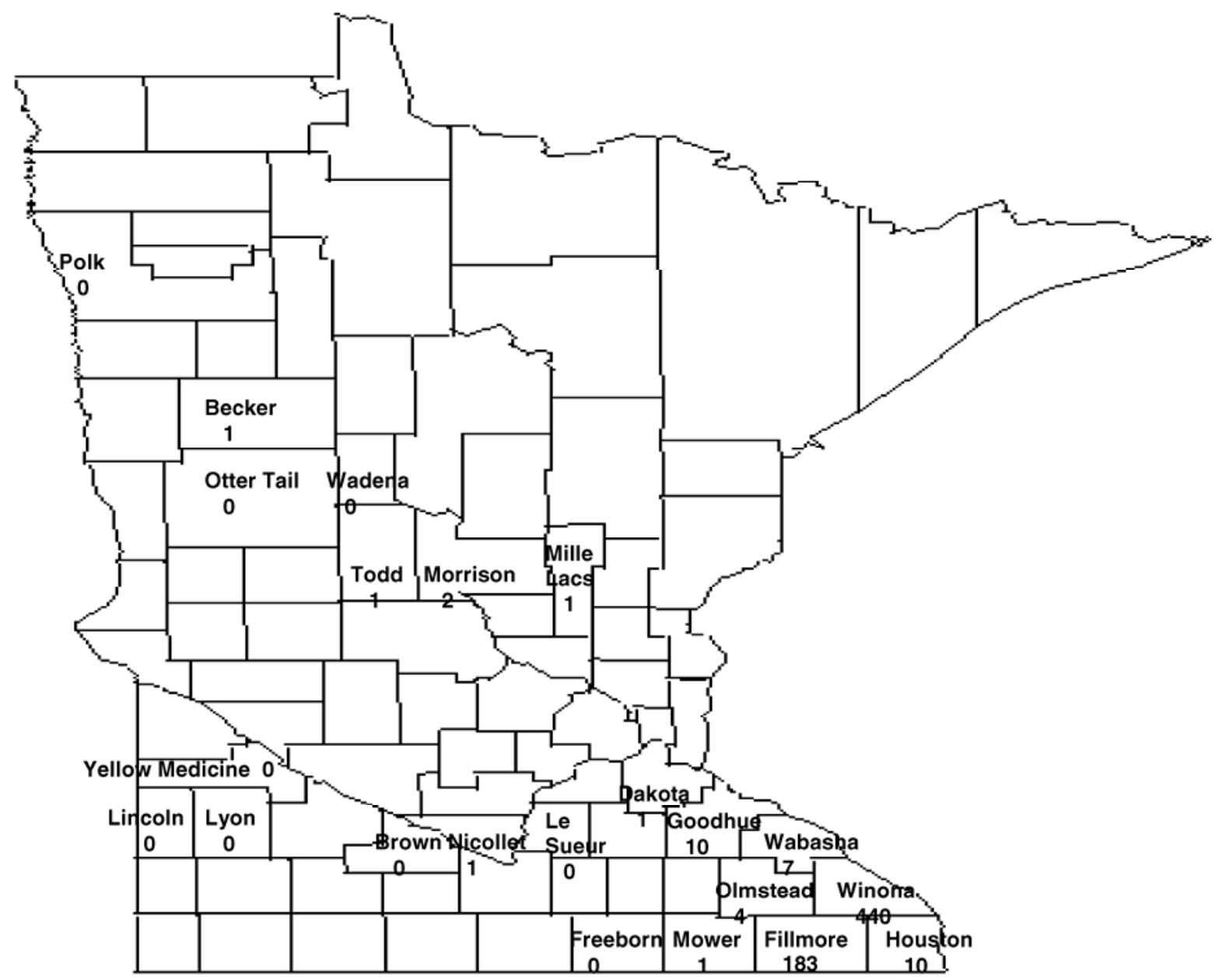

Fig. 2. Map of Minnesota indicating counties surveyed and where barberry bushes were located, 1998 to 2002. 
ier and more acidic $(9,11,17)$. In addition, barberry seed germination and seedling survival is favored by shade $(2,4,5,18,19)$, hence the wooded terrain of southeastern Minnesota provides ideal conditions for barberry growth and development in comparison with the sparsely wooded prairie environment typical of the western districts where seeds and seedlings are exposed to more direct sunlight. Sites containing many barberry bushes, such as the two sites in Winona County and the single site in Fillmore County, may represent second and third and subsequent generations from the original barberry bushes that sprouted on these sites after the termination of the program.

The abundance of barberry bushes in southeastern Minnesota, in contrast to the western counties, is probably also related to past eradication activities. Historically, locating and removing barberry was much more difficult in the hilly and wooded terrain of the southeast than in the more open, prairie counties in the western districts. Topography in the western districts allowed for more thoroughness in locating and removing bushes, seedlings, and sprouts (10). Thus, archival data suggest the potential for large numbers of viable seeds and undisclosed sprouting bushes in the southeast at the end of the eradication program.

The survey indicates that few barberry bushes exist in regions of important wheat production in Minnesota. Out of the 72 sites surveyed in the present study, a single bush was found on a site (Becker County) in an area of major wheat production
$(>10,000$ ha). The low occurrence of bushes in these areas is further evidenced by the fact that there have been no significant stem rust epidemics on wheat in the state since the 1960s (13). The lack of epidemics is attributed to the extensive removal of barberry bushes during the eradication program (reduction in the amount of initial inoculum and delay of disease onset) and to the development of stem rust-resistant wheat cultivars by plant breeders $(7,13)$. Barberry bushes generally do not present an immediate problem unless they occur in close proximity $(<100$ $\mathrm{m})$ to wheat fields $(14,15)$. Basidiospores produced by telia in overwintered wheat straw are short-lived and do not survive long-distance transport. Thus, basidio-

Table 2. Number of sites surveyed and numbers of barberry bushes found on selected active sites in districts and counties in Minnesota surveyed between 1998 and 2002

\begin{tabular}{|c|c|c|c|c|}
\hline District & Counties & $\begin{array}{c}\text { Proportion of } \\
\text { sites with bushes }\end{array}$ & Bushes per site & $\begin{array}{l}\text { Wheat production } \\
\text { (ha) }^{\mathrm{a}}\end{array}$ \\
\hline \multirow[t]{3}{*}{ Central $^{b}$} & Morrison & $1 / 5$ & 2 & 346 \\
\hline & Todd & $1 / 5$ & 1 & 2,154 \\
\hline & Wadena & $0 / 4$ & 0 & 286 \\
\hline \multirow[t]{2}{*}{ Northwest } & Becker & $1 / 2$ & 1 & 28,141 \\
\hline & Polk & $0 / 2$ & 0 & 149,886 \\
\hline \multirow[t]{8}{*}{ Southeast } & Fillmore & $10 / 12$ & $\begin{array}{c}8,3,1,1,159 \\
2,2,1,5,1\end{array}$ & 92 \\
\hline & Goodhue & $3 / 3$ & $4,5,1$ & 271 \\
\hline & Houston & $6 / 6$ & $1,3,1,1,3,1$ & 130 \\
\hline & Mower & $1 / 1$ & 1 & 306 \\
\hline & Olmstead & $1 / 2$ & 4 & 56 \\
\hline & Wabasha & $1 / 1$ & 7 & 235 \\
\hline & Winona & $4 / 5$ & $120,7,13,300$ & 46 \\
\hline & Dakota & $1 / 1$ & 1 & 1,030 \\
\hline \multirow[t]{2}{*}{ Southwest } & Lincoln & $0 / 1$ & 0 & 3,165 \\
\hline & Lyon & $0 / 2$ & 0 & 2,056 \\
\hline \multirow[t]{4}{*}{ South central } & Nicollet & $1 / 5$ & 1 & 916 \\
\hline & La Sueur & $0 / 1$ & 0 & 937 \\
\hline & Freeborn & $0 / 1$ & 0 & 18 \\
\hline & Brown & $0 / 2$ & 0 & 1,029 \\
\hline East central & Mille Lacs & $1 / 1$ & 1 & 212 \\
\hline \multirow[t]{2}{*}{ West central } & Ottertail & $0 / 8$ & 0 & 29,172 \\
\hline & Yellow Medicine & $0 / 2$ & 0 & 514 \\
\hline
\end{tabular}

a From 1997 U.S. Agricultural Census.

b Number of sites surveyed in each district: central $=14$, northwest $=4$, southeast $=31$, southwest $=3$, south central $=9$, east central $=1$, west central $=10$.

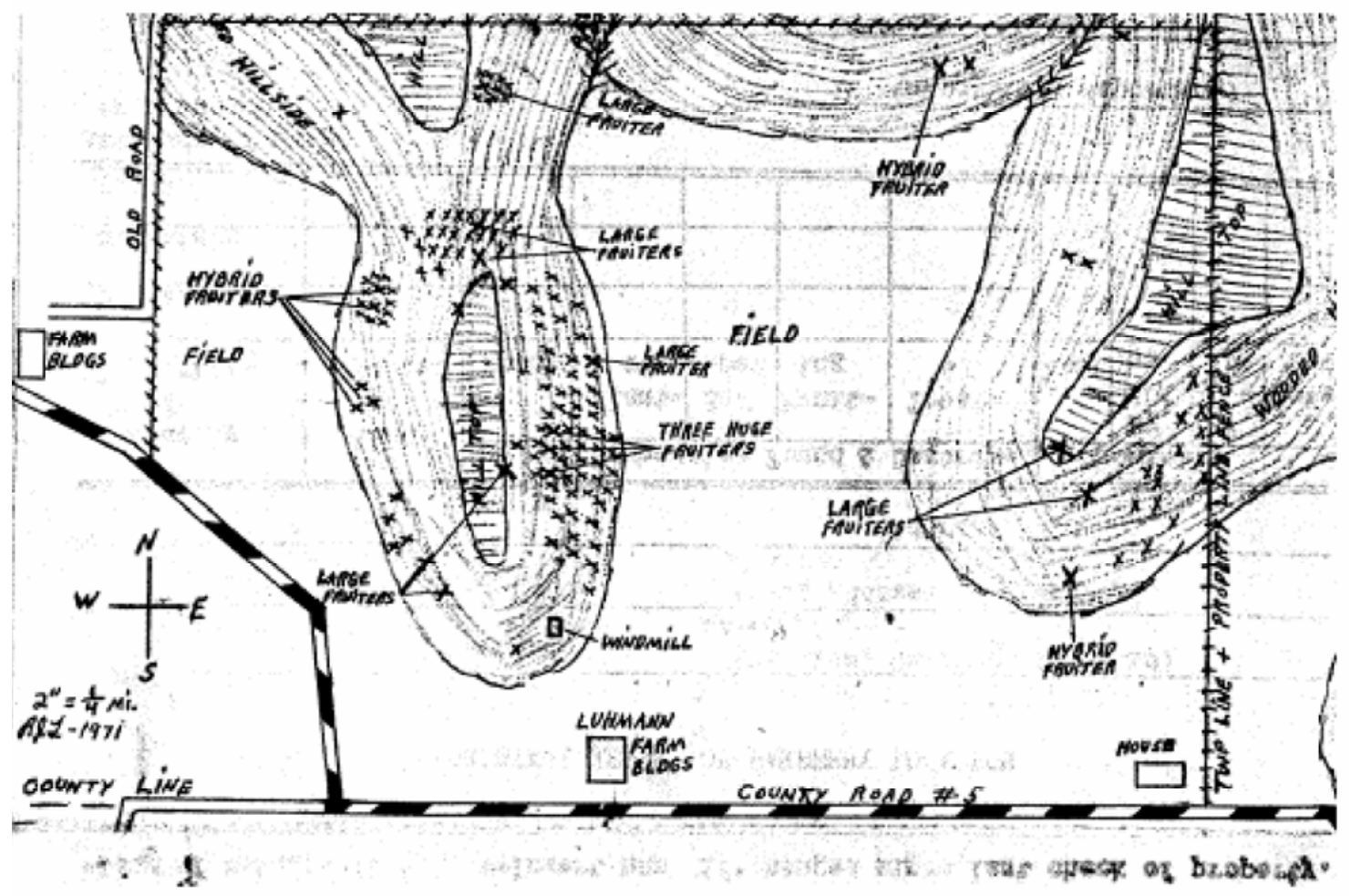

Fig. 3. Hand-drawn map of a barberry eradication site in Minnesota from a historical site locator form (L-form). 
spores produced at greater distances from barberry bushes are unlikely to cause aecial infections that could serve as primary inoculum for stem rust epidemics in wheat. Also, aeciospores are mostly dispersed over relatively short distances (1416). With only small numbers of barberry bushes scattered mostly over areas remote from wheat fields, the primary inoculum contributed by aeciospores is generally insignificant compared with the seasonal influx of urediniospores from fields of ripening wheat. Evidence suggests that even a single bush can produce enough aeciospores to initiate a damaging local epidemic of stem rust when adjacent to wheat fields $(14,15)$. So far, aecia have not been observed on the Becker County barberry bush, which suggests either that there have not been sufficient numbers of telia produced or that the germination of teliospores on wheat straw in the vicinity of that bush has not been adequate for infection of the bush.

Even though nearly all of the known barberry bushes in Minnesota are located too far from important wheat producing districts to constitute an immediate threat of regional epidemics of stem rust, barberries may still represent a long-term danger. Aecia of $P$. graminis f. sp. tritici were found on barberry bushes in Fillmore and Winona counties in 1995 (8), in Houston, Fillmore, and Winona counties in 2000, and in Winona County in 2002 (10). Apparently these aecial infections resulted from basidiospores produced by teliospores on susceptible wild grasses in the vicinity of these barberry bushes that were infected by $P$. graminis f. sp. tritici, because there was no wheat production near the bushes. Races of $P$. graminis f. sp. tritici in wheat fields are likely to occur also on susceptible wild grasses in and around the wheat fields. Thus, spread of $P$. graminis f. sp. tritici on wild grasses away from wheat fields may provide an indirect connection between aecial infections on barberry and uredinial infections on wheat. While the amount of spread from barberry to wheat via susceptible grasses may be epidemiologically insignificant, the danger is that new virulent races of $P$. graminis $\mathrm{f}$. sp. tritici may be produced in the sexual stage on barberry and eventually find their way to wheat. For example, race 15B, which caused the devastating wheat stem rust epidemics of 1953 and 1954 in Minnesota and the Dakotas, was first found on a barberry bush in Iowa in 1939 (7). The probability that such new virulent races may occur and spread to wheat will increase if the numbers of barberry bushes in Minnesota continues to increase. The potential danger of new wheat stem rust races would also increase if barberry spreads into wheat growing areas or if wheat production were to increase in southeastern Minnesota in the future.

It will be difficult, if not impossible, to totally eradicate $B$. vulgaris from the wooded, hilly terrain of southeastern Minnesota. Nevertheless, the large concentrations of barberry bushes should be eliminated as they are identified. The risks of existing barberry bushes are twofold: (i) they produce an abundance of seed each year, some of which may be carried long distances toward more important wheat producing regions by birds that feed on the berries, and (ii) if wheat production were ever to expand in southeastern Minnesota, that would make it much more likely that the link between the sexual cycle and the disease cycle of wheat stem rust would be reestablished with a consequent increase in the numbers of stem rust races that wheat breeders would have to combat. Many active barberry sites in southeastern Minnesota remain to be resurveyed. These can be located by use of the L-forms from the barberry eradication program which have been preserved. Fortunately, there are few barberry sites in western Minnesota. All of the sites that had been designated as active sites in the northwestern, west central, and southwestern districts of Minnesota have been revisited in the present survey, and only the one site in Becker County was found to have a barberry bush. That barberry bush should be destroyed before it contributes to further reproduction of barberry in that important wheat growing area. In addition, more effort is recommended toward finding and destroying barberry bushes in the central and south central districts of Minnesota, which are nearer than the southeast district to the areas of major wheat production. Failure to take these steps soon may lead to detrimental consequences in the long term.

\section{LITERATURE CITED}

1. Atwood, H. 1930. Experimental Studies on Common Barberry Seeds and Seedlings, 19261930. Barberry Eradication Records, University of Minnesota Archives.

2. Atwood, H., and Stover, W. G. 1936. The Maumee Seed Germination and Seedling Survival
Experiments 1930-1936. Barberry Eradication Records, University of Minnesota Archives.

3. Campbell, C. L., and Long, D. L. 2001. The campaign to eradicate the common barberry in the United States. Pages 16-51 in: Stem Rust of Wheat: From Ancient Enemy to Modern Foe. P. D. Peterson, ed. American Phytopathological Society, St. Paul, MN.

4. Cotter, R. U. 1942. Ecology of Berberis vulgaris. Barberry Eradication Records, University of Minnesota Archives.

5. Denton, R. R. 1952. Germination and Establishment of the Common Barberry (Berberis vulgaris L.). M.S. thesis. Iowa State College, Ames.

6. Flake, M. G. 1945. Birds and Barberry. Barberry Eradication Records, University of Minnesota Archives.

7. Leonard, K. J. 2001. Stem rust-future enemy? Pages 119-146 in: Stem Rust of Wheat: From Ancient Enemy to Modern Foe. P. D. Peterson, ed. American Phytopathological Society, St. Paul, MN.

8. McVey, D. V., Long, D. L., and Roberts, J. J. 1997. Races of Puccinia graminis in the United States during 1995. Plant Dis. 81:306310.

9. Melander, L. W., and Brueggeman, E. 1935. Report of the progress of the Barberry Eradication Campaign in the State of Minnesota, 1934. Barberry Eradication Records, University of Minnesota Archives.

10. Peterson, P. D. 2003. The Common Barberry: The Past and Present Situation in Minnesota and the Risk of Wheat Stem Rust Epidemics. $\mathrm{PhD}$ thesis. North Carolina State University, Raleigh.

11. Reddy, W. F. 1924. Experimental Studies with Common Barberry Seed and Seedlings. Michigan Annual Report. Barberry Eradication Records, University of Minnesota Archives.

12. Robbins, W. W. 1921. Notes on Ecology of the Common Barberry and Methods of Eradication. Barberry Eradication Records, University of Minnesota Archives.

13. Roelfs, A. P. 1982. Effects of barberry eradication on stem rust in the United States. Plant Dis. 66:177-181.

14. Roelfs, A. P. 1985. Epidemiology in North America. Pages 403-434 in: The Cereal Rusts, vol. 2. W. R. Bushnell and A. P. Roelfs, eds. Academic Press, Inc., Orlando, Florida.

15. Roelfs, A. P. 1985. Wheat and rye stem rust. Pages 3-37 in: The Cereal Rusts, vol. 2. W. R. Bushnell and A. P. Roelfs, eds. Academic Press, Inc., Orlando, Florida.

16. Rowell, J. B., to Flaskerd, R., December 2, 1975. Minnesota Department of Agriculture, St. Paul, MN.

17. Shepherd, D. R. 1944. Summary of Ecological, Morphological, and Chemical Eradication Studies of Importance to the Barberry Eradication Project. Barberry Eradication Records, University of Minnesota Archives.

18. U.S. Dep. Agric. Agric. Res. Serv., Bureau of Entomology and Plant Quarantine. Barberry Eradication Office, Columbus, Ohio. 1931. Barberry Eradication Records, University of Minnesota Archives.

19. U.S. Dep. Agric. Agric. Res. Serv., Forest Service. 1948. Seed Manual. Pub. 654. pp. 97-98. 